\title{
PAAUGLIŲ MITYBA SVEIKATĄ STIPRINANČIOSE MOKYKLOSE
}

\author{
Sigitas Griškonis ${ }^{1,2}$, Aiva Dabašinskiene் ${ }^{2}$, Birutė Strukčinskienè ${ }^{2}$ \\ ${ }^{1}$ Klaipèdos universitetine ligonine, ${ }^{2}$ Klaipédos universiteto Sveikatos mokslu fakultetas
}

Raktažodžiai: mityba, paaugliai, sveikatą stiprinanti mokykla, mokiniai, sveika gyvensena.

\section{Santrauka}

Tinkama mityba paauglystès laikotarpiu mažina mažakraujystès, vystymosi sutrikimų, antsvorio ir kitų sveikatos problemų riziką. Sveikatą stiprinančios mokyklos padeda paaugliams formuoti sveikatai įtakos turinčią elgseną. Darbo tikslas buvo aptarti paauglių mitybos ypatumus sveikatą stiprinančiose mokyklose. Atlikta apklausa raštu. Buvo tirti paauglių mitybos ịpročiai sveikatą stiprinančiose mokyklose ir mokyklose, neįsitraukusiose ị sveikatą stiprinančių mokyklų tinklą. Tyrimas atliktas keturiose Klaipèdos regiono mokyklose. Dvi iš jų yra sveikatą stiprinančios mokyklos, kitos dvi - atsitiktinai atrinktos mokyklos. Ugdymo ịstaigose parenkant tyrimui klases taikyta atsitiktinè lizdinè atranka. Statistinè duomenų analizè atlikta naudojantis SPSS 20 programine ịranga. Taikytas $\chi^{2}$ kriterijus. Statistinis hipotezių reikšmingumas patvirtintas, kai $\mathrm{p}<0,05$. Tyrime dalyvavo 487 ugdymo įstaigų 9-12 klasių mokiniai (15-19 metų): 223 (45,8 proc.) vaikinai ir 264 (54,2 proc.) merginos. Apklausti 242 (49,7 proc.) sveikatą stiprinančių mokyklų (SSM) ir 245 (50,3 proc.) neįsitraukusių i SSM tinklą respondentai. Tyrimo metu nustatyta, kad kasdien mokykloje pietauja du kartus daugiau mokinių iš sveikatą stiprinančių mokyklų (SSM), nei mokinių, lankančių mokyklas, nedalyvaujančias sveikatą stiprinančių mokyklų tinkle. SSM mokiniai valgo keturis ir daugiau kartų per dieną, o mokiniai mokyklose, neịsitraukusiose ị sveikatą stiprinančių mokyklų tinklą - tris kartus per dieną. SSM tinkle nedalyvaujančiose mokyklose daugiau mokinių nurodè, kad jų mokyklose prekiaujama nesveiku maistu, nei SSM mokyklose. SSM mokiniai rečiau valgo greito maisto produktų, geria kokakolos bei kitų saldžių gazuotų gèrimų ir dažniau valgo sriubos, tačiau valgo mažiau juodos duonos ir šviežių vaisių, nei sveikatą stiprinančių mokyklų veikloje nedalyvaujančių mokyklų ugdytiniai. Maistą mokykloje pagal naudą sveikatai renkasi tik apie 10 proc. paauglių ir SSM mokyklose, ir įprastinėse mokyklose. Iprastines mokyklas lankantys mokiniai dažniau kalbasi su šeimos nariais apie sveiką mitybą, dažniau laikosi sveikos mitybos principų, turi daugiau žinių apie sveiką mitybą, nei SSM mokiniai, tačiau savo mitybos ịpročius labiau linkę keisti SSM ugdytiniai. Sveikos gyvensenos pamokose apie sveiką mitybą norètų sužinoti apie pusę SSM mokinių ir trečdalis mokinių, lankančių ịprastines mokyklas.

\section{Ivadas}

Sveika ir visaverte mityba daro poveikị fizinei ir protinei žmogaus raidai, darbingumui ir ilgaamžiškumui. Sveika mityba - sveikatos pagrindas. Itvairių mokslininkų duomenimis, mitybos ịpročiai turi ịtakos mūsų sveikatai net 25-30 proc. [1].

Tinkama mityba paauglystės laikotarpiu mažina mažakraujystės, vystymosi sutrikimų, antsvorio ir kitų sveikatos problemų riziką. Vaikystejje mitybos ịpročius daugiau ar mažiau lemia tèvų maitinimosi modelis, tačiau paauglystejje, kada išauga saviraiškos, nepriklausomybès poreikis, paauglių mitybos ịpročiai gali kisti. Paaugliai domisi savo išvaizda, jiems pasidaro svarbu neišsiskirti iš bendraamžių grupès [2].

Dauguma vaikų ir paaugliu stengiasi neatsilikti nuo šiuolaikinès mados ir bando laikytis ịvairių dietų, kurios turi savo pasekmes. Laikantis ịvairių dietų atsiranda valgymo sutrikimai: nervinè bulimija ir nerviné anoreksija. Ivvairių autorių duomenimis, valgymo sutrikimų turi iki 4 proc. paauglių. Nervinès anoreksijos atvejų diagnozuojama vis daugiau: šis sutrikimas $10-20$ kartų daugiau diagnozuojamas mergaitèms nei berniukams [3].

Moksliniai tyrimai pagrindžia vaikų ir paauglių, kaip ir visų gyventojų, tiesioginį mitybos ryšį su įvairiais socialiniais ir ekonominiais veiksniais: maisto produktų kainomis ir jų rinkodara, sveikatai palankių produktų prieinamumu, nedarbu, šeimos turtine padètimi, reklama bei kitais veiks- 
niais. Skirtingai nuo suaugusiujų, vaikų mitybą veikia dar daugiau veiksnių: gyvensenos formavimosi ypatumai, žinių ir patirties stoka, tèvų elgesio ir auklejjimo modeliai, šeimos narių sudètis, bendraamžių įtaka, mokyklos strategija ir veikla sprendžiant mokinių mitybos klausimus [4].

Mokslininkai siūlo daugiau dėmesio skirti vaikų ir paauglių valgymo ịpročiams, vaikų mitybai mokyklose, namuose, pabrèžiama mitybos specialistų įtaka, tèvų vaidmuo formuojant ir ugdant vaikų sveikos mitybos įpročius [5]. Mokinių maitinimas mokyklose turi būti organizuojamas atsižvelgiant $\mathfrak{i}$ fiziologinius mokinių poreikius, vaiku amžiaus ypatumus bei sveikos mitybos principus ir taisykles. Maisto produktų tiekimas, maisto tvarkymo įranga ir maisto tvarkymas turi atitikti visuomenès sveikatos priežiūros bei kitų teisès aktų reikalavimus [6].

Maitinimas - viena svarbiausių veiklos sričių vaikų ugdymo ịstaigose. Ji veikia ne tik vaikų sveikatą, atsparumą ligoms, tinkamą augimą, bet ir mokymosi rezultatus. Racionalios mitybos ugdymas yra viena iš svarbiausių šio laikmečio ugdymo sričių. Sveikatą stiprinančios mokyklos siekia igyvendinti pagrindinị tikslą, besivadovaudamos 12 kriterijų. Iš jų devintas yra „Sveikos mitybos ịpročių formavimas". Veiklos kryptys sveikatą stiprinančiose mokyklose yra šios:

- Mitybos normų laikymasis organizuojant maitinimą mokykloje.

- Mokyklos maisto blokų darbuotojų dalyvavimas igyvendinant sveikos mitybos strategiją visoje mokykloje.

- Sąlygur maitinimui organizuoti (patalpu ịrengimas, maisto gaminimas, valgymui patalpų, pakankamos trukmès pertraukų ir darbo numatymas) sudarymas.

- Bufetų aprūpinimas vaikų mitybai tinkamo asortimento produktais.

- Ryšių su tèvais palaikymas mokinių maitinimo klausimais [7].

- Sveikatą stiprinančios mokyklos paaugliams padeda formuoti sveikatai įtakos turinčią elgseną.

Paaugliai padedami mokytojų, visuomenès sveikatos priežiūros specialistų ir tèvų turi patys pasirinkti, kokiu būdu rūpintis savo sveikata: pasirinkti sveiką mitybą ar nesaugų maistą (nesveiką mitybą). Mokyklose turi būti sudarytas prieinamumas sveikai mitybai ir geriamajam vandeniui, kad paaugliai galètų rūpintis savo ir kitų sveikata.

Darbo tikslas - aptarti paauglių mitybos ypatumus sveikatą stiprinančiose mokyklose.

\section{Tyrimo metodika}

Atlikta apklausa raštu. Buvo tirti paauglių mitybos ipročiai sveikatą stiprinančiose mokyklose ir mokyklose, neįsitraukusiose i sveikatą stiprinančių mokyklų tinklą.
Klaipėdos regione yra dvi sveikatą stiprinančios mokyklos (SSM). Tyrimas atliktas keturiose Klaipedos regiono mokyklose. Dvi iš jų yra sveikatą stiprinančios mokyklos, kitos dvi - atsitiktinai atrinktos mokyklos. Ugdymo istaigose parenkant tyrimui klases taikyta atsitiktinè lizdinè atranka. Statistine duomenu analize atlikta naudojantis SPSS 20 programine įranga. Taikytas $\chi^{2}$ kriterijus. Statistinis hipotezių reikšmingumas patvirtintas, kai $\mathrm{p}<0,05$.

Tyrime dalyvavo 487 ugdymo įstaigu 9-12 klasių mokiniai (15-19 metu): 223 (45,8 proc.) vaikinai ir 264 (54,2 proc.) merginos. Apklausti 242 (49,7 proc.) sveikatą stiprinančių mokyklų (SSM) ir 245 (50,3 proc.) neịsitraukusių i SSM tinkla respondentai. Tyrimui naudotas Klaipėdos universiteto Sveikatos mokslų fakulteto Visuomenès sveikatos katedros mokslininkų sudarytas klausimynas. Buvo išdalintos 498 anketos, analizuotos 487 užpildytos anketos (anketų grižtamumas 97,8\%). Jaunesni nei 16 metų respondentai tyrime dalyvavo tik su raštišku tèvų sutikimu. Tyrimui atlikti buvo gautas Bioetikos komiteto leidimas.

\section{Rezultatai ir jų aptarimas}

Tyrimo metu buvo analizuoti paauglių mitybos įpročiai sveikatą stiprinančiose mokyklose ir mokyklose, neįsitraukusiose ị sveikatą stiprinančių mokyklų tinklą. Tyrimo rezultatai parodè, kad mokykloje kasdien pietauja apie pusé (48,3 proc.) paauglių sveikatą stiprinančiose mokyklose (SMM) ir ketvirtadalis (23,3 proc.) paauglių, kurie mokosi mokyklose, neisitraukusiose ì sveikatą stiprinančiu mokyklų tinklą. Pietų mokykloje niekada nevalgo 31,0 proc. paaugliu, kurie mokosi mokyklose, neisitraukusiose i sveikatą stiprinančių mokyklų tinklą, o sveikatą stiprinančiose mokyklose tik 9,1 proc. pagalių niekada nepietauja mokykloje. Tyrimas atskleidè, kad sveikatą stiprinančiose mokyklose paaugliai statistiškai reikšmingai dažniau valgo pietus mokykloje, negu paaugliai, lankantys mokyklas, nedalyvaujančias sveikatą stiprinančių mokyklų judejjime $\left(\chi^{2}=50,8 ; 11 s=2 ; p<0,001\right)$.

Tyrimo metu paaiškèjo, kad 53,3 proc. mokinių sveikatą stiprinančiose mokyklose valgo keturis ir daugiau kartu per dieną, o 39,7 proc. - tris kartus per dieną, kai tuo tarpu 48,2 proc. mokinių mokyklose, neịsitraukusiose ị sveikatą stiprinančių mokyklų tinklą, valgo tris kartus per dieną, 30,2 proc. - keturis ir daugiau kartu per dieną, ir 17,1 proc. - du kartus per dieną. SMM mokiniai valgo reikšmingai daugiau kartų per dieną, negu mokiniai mokyklose, neịsitraukusiose ị sveikatą stiprinančių mokyklų tinklą $\left(\chi^{2}=38,7\right.$; $11 \mathrm{~s}=3 ; \mathrm{p}<0,001)$.

Kadangi mūsų šalies mokyklose draudžiama prekiauti nesveiku maistu, tyrimu norèta išsiaiškinti, kaip šio draudimo laikomasi. Paaugliai buvo klausiami, ar jų mokykloje 
prekiaujama nesveiku maistu. Iš tyrimo rezultatų matyti, kad dažniau prekiaujama nesveiku maistu mokyklose, neįsitraukusiose ì sveikatą stiprinančių mokyklų tinklą $\left(\chi^{2}=14,4 ; 11 s=1 ; \mathrm{p}<0,001\right)$. Apie pusè respondentų $(53,9$ proc.) nurode, kad šiose mokyklose prekiaujama nesveikais maisto produktais. $36,8 \%$ mokinių iš SSM nurode, kad jų mokyklose prekiaujama nesveiku maistu.

Tyrimo metu buvo siekiama išsiaiškinti, kaip dažnai 9-12 klasių mokiniai valgo ịvairius maisto produktus. Mitybos įpročių rezultatai buvo palyginti tarp sveikatą stiprinančių mokyklų ugdytinių ir mokinių, kurie lanko įprastines mokyklas (1 lentelè). Tyrimo rezultatai parodè, kad paaugliai mokyklose, neįsitraukusiose ị SSM tinklą, reikšmingai dažniau valgo juodą duoną, negu mokiniai iš sveikatą stiprinančių mokyklų $\left(\chi^{2}=22,6 ; 11 s=3 ; p<0,001\right)$. Juodą duoną kasdien arba beveik kasdien valgo apie pusę $(50,2$ proc.) mokinių iš ịprastinių mokyklų, ir 33,4 proc. - iš sveikatą stiprinančių mokyklų. Kokakolą ir kitus saldžius gazuotus gèrimus reikšmingai rečiau geria SSM ugdytiniai $\left(\chi^{2}=10,2 ; 11 s=3 ; p=0,017\right)$. Beveik penktadalis $(19,2 \%)$ respondentų iš sveikų mokyklų tinkle nedalyvaujančių mokyklų kokakolą ir kitus saldžius gazuotus gèrimus vartoja kasdien arba 3-5 dienas per savaitę. Greito maisto produktus ( mèsainius, dešrainius, bulvių traškučius ir pan.) dažniau valgo paaugliai iš ugdymo ịstaigų, nedalyvaujančių sveikatą stiprinančių mokyklų tinkle $\left(\chi^{2}=10,6 ; 11 s=3 ; p=0,014\right)$. Tyrimas parodé, kad mokiniai mokyklose, neicsitraukusiose i SSM tinklą, statistiškai reikšmingai dažniau, negu mokiniai SSM valgo šviežius vaisius $\left(\chi^{2}=12,5 ; 11 \mathrm{~s}=3 ; \mathrm{p}=0,006\right)$. 16,9 proc. SSM tinkle dalyvaujančiu ir 8,2 proc. SSM veikloje nedalyvaujančių mokyklų mokinių šviežius vaisius valgo 1 kartą per savaitę, 29,3 proc. SSM ir 27,8 proc. ne

1 lentelè. Maisto produktų vartojimas tarp paauglių (SSM - Sveikata stiprinanti mokykla)

\begin{tabular}{|c|c|c|c|c|c|c|}
\hline Produktas & Mokykla & $\begin{array}{c}\text { Niekada } \\
\mathrm{N}(\%)\end{array}$ & $\begin{array}{c}\text { 1-2 kartai per } \\
\text { sav. } \mathrm{N}(\%)\end{array}$ & $\begin{array}{c}\text { 3-5 kartai per } \\
\text { sav. N(\%) }\end{array}$ & $\begin{array}{c}\text { Kasdien } \\
\mathrm{N}(\%) \\
\end{array}$ & p-reikšmė \\
\hline \multirow[t]{2}{*}{ Juoda duona } & SSM & $74(30,6)$ & $87(36,0)$ & $47(19,4)$ & $34(14,0)$ & \multirow[t]{2}{*}{$\mathrm{p}<0,001$} \\
\hline & ne SSM & $35(14,3)$ & $87(35,5)$ & $72(29,4)$ & $51(20,8)$ & \\
\hline \multirow{2}{*}{$\begin{array}{l}\text { Kokakola ir } \\
\text { kt. saldūs, } \\
\text { gazuoti } \\
\text { gèrimai }\end{array}$} & SSM & $96(39,7)$ & $120(49,6)$ & $22(9,1)$ & $4(1,6)$ & \multirow[t]{2}{*}{$\mathrm{p}=0,017$} \\
\hline & ne SSM & $73(29,8)$ & $125(51,0)$ & $35(14,3)$ & $12(4,9)$ & \\
\hline \multirow{2}{*}{$\begin{array}{l}\text { Greito maisto } \\
\text { produktai }\end{array}$} & SSM & $86(35,5)$ & $130(53,7)$ & $20(8,3)$ & $6(2,5)$ & \multirow[t]{2}{*}{$\mathrm{p}=0,014$} \\
\hline & ne SSM & $61(24,9)$ & $137(55,9)$ & $38(15,5)$ & $9(3,7)$ & \\
\hline \multirow[t]{2}{*}{ Švieži vaisiai } & SSM & $41(16,9)$ & $71(29,3)$ & $74(30,6)$ & $56(23,2)$ & \multirow[t]{2}{*}{$\mathrm{p}=0,006$} \\
\hline & ne SSM & $20(8,2)$ & $68(27,8)$ & $74(30,2)$ & $83(33,8)$ & \\
\hline
\end{tabular}

2 lentelè. Sriubos valgymo dažnis tarp paauglių $\chi^{2}=15,2 ; l l s=2 ; p<0,001$

\begin{tabular}{|l|l|c|c|}
\hline Mokykla & $\begin{array}{c}\text { Niekada } \\
\text { nevalgo } \\
\text { N (proc.) }\end{array}$ & $\begin{array}{c}\text { Kelis } \\
\text { kartus per } \\
\text { savaitę } \\
\text { N (proc.) }\end{array}$ & $\begin{array}{c}\text { Kasdien } \\
\text { N } \\
\text { (proc.) }\end{array}$ \\
\hline SSM & $15(6,2)$ & $204(84,3)$ & $23(9,5)$ \\
\hline $\begin{array}{l}\text { Mokykla } \\
\text { neisitraukusi } \\
\text { î SSM tinklą }\end{array}$ & $36(14,7)$ & $171(69,8)$ & $38(15,5)$ \\
\hline
\end{tabular}

3 lentelè. Mokinių maisto pasirinkimo kriterijai mokyklos valgykloje

\begin{tabular}{|l|l|l|l|l|l|l|}
\hline Mokykla & $\begin{array}{l}\text { Kaina } \\
\text { N (proc.) }\end{array}$ & $\begin{array}{l}\text { Išvaizda } \\
\text { N (proc.) }\end{array}$ & $\begin{array}{l}\text { Porcijos } \\
\text { dydis } \\
\text { N (proc.) }\end{array}$ & $\begin{array}{l}\text { Nauda } \\
\text { sveikatai } \\
\text { N (proc.) }\end{array}$ & $\begin{array}{l}\text { Skonis } \\
\text { N (proc.) }\end{array}$ & $\begin{array}{l}\text { Ką pataria } \\
\text { tėvai } \\
\text { N (proc.) }\end{array}$ \\
\hline SSM & $99(40,9)$ & $11(4,5)$ & $30(12,4)$ & $25(10,3)$ & $76(31,4)$ & $1(0,5)$ \\
\hline $\begin{array}{l}\text { Mokykla } \\
\text { neisitraukusi i } \\
\text { SSM tinklą }\end{array}$ & $70(28,6)$ & $27(11,0)$ & $21(8,6)$ & $25(10,2)$ & $99(40,4)$ & $3(1,2)$ \\
\hline Iš viso & $169(34,7)$ & $38(7,8)$ & $51(10,5)$ & $50(10,3)$ & $175(35,9)$ & $4(0,8)$ \\
\hline
\end{tabular}

4 lentelè. Šaltiniai, iš kurių mokiniai norètų sužinoti apie sveiką mitybą

\begin{tabular}{|l|l|l|l|l|}
\hline Mokykla & $\begin{array}{l}\text { Internetu } \\
\text { N (proc.) }\end{array}$ & $\begin{array}{l}\text { Žiūrint } \\
\text { TV } \\
\text { N (proc.) }\end{array}$ & $\begin{array}{l}\text { Skaitant } \\
\text { literatūrą } \\
\text { N (proc.) }\end{array}$ & $\begin{array}{l}\text { Sveikos } \\
\text { gyvensenos } \\
\text { pamokose } \\
\text { N (proc.) }\end{array}$ \\
\hline SSM & $51(21,1)$ & $51(21,1)$ & $11(4,5)$ & $129(53,3)$ \\
\hline $\begin{array}{l}\text { Mokykla } \\
\text { neisitraukusi i } \\
\text { SSM tinklą }\end{array}$ & $98(40,0)$ & $65(26,5)$ & $14(5,7)$ & $68(27,8)$ \\
\hline Iš viso & $149(30,6)$ & $116(23,8)$ & $25(5,1)$ & $197(40,5)$ \\
\hline
\end{tabular}

5 lentelè. Mokinių subjektyvus savo žinių apie sveiką mitybą vertinimas $\chi^{2}=13,1 ; l l s=2 ; p=0,001$

\begin{tabular}{|l|c|c|c|}
\hline \multicolumn{1}{|c|}{ Mokykla } & $\begin{array}{c}\text { Taip } \\
\text { N (proc.) }\end{array}$ & $\begin{array}{c}\text { Abejoju } \\
\text { N (proc.) }\end{array}$ & $\begin{array}{c}\text { Ne } \\
\text { N (proc.) }\end{array}$ \\
\hline SSM & $85(35,1)$ & $141(58,3)$ & $16(6,6)$ \\
\hline $\begin{array}{l}\text { Mokykla } \\
\text { neịsitraukusi } i \underset{t}{\text { SSM tinklą }}\end{array}$ & $123(50,2)$ & $103(42,0)$ & $19(7,8)$ \\
\hline
\end{tabular}


SSM mokinių šviežius vaisius valgo 2 kartus per savaitę, 30,6 proc. SSM ir 30,2 proc. ne SSM ugdytinių šviežius vaisius valgo 3 kartus per savaitę, o 23,2 proc. SSM ir 33,8 proc. ne SSM paauglių nurodè, kad jie šviežias daržoves valgo 4 ir daugiau kartų per savaitę.

Tyrimo metu buvo domètasi, kaip dažnai paaugliai valgo sriubą. Tyrimo rezultatai atskleidè, kad 89,5 proc. 9-12 klasių mokinių valgo sriubą kasdien arba kelis kartus per savaitę. Analizuojant apklausos rezultatus pagal mokyklas paaiškèjo, kad sveikatą stiprinančių mokyklų mokiniai reikšmingai dažniau valgo sriubą, negu paaugliai iš mokyklų, neįsitraukusių ị sveikatą stiprinančių mokyklų tinklą $\left(\chi^{2}=15,2 ; 11 \mathrm{~s}=2 ; \mathrm{p}<0,001\right)$ ( 2 lentelè).

Norint išsiaiškinti mokinių racionalios mitybos ịpročius buvo prašoma nurodyti pagrindinius kriterijus, kuriais remdamiesi jie renkasi maisto produktus mokyklos valgykloje (3 lentelè). Pagal tyrimo duomenis galima išskirti du pagrindinius maisto pasirinkimo kriterijus. Tai yra skonio savybės (atsake 35,9 proc. visų paauglių) ir kaina (atsaké 34,7 proc. visų paauglių). Šie du kriterijai žymèti kaip pagrindiniai tiek sveikatą stiprinančiose mokyklose, tiek mokyklose, neịsitraukusiose ị sveikatą stiprinančių mokyklų tinklą. I naudą sveikatai rinkdamiesi maistą atsižvelgia tik apie 10 proc. paauglių ir iš SSM, ir iš ịprastinių mokyklų (reikšmingų skirtumų tarp mokyklų kategorijų nenustatyta).

Kalbejjimas šeimoje apie sveiką mitybą yra viena iš mitybos ịpročių valdymo priemonių. Tyrimo metu buvo klausiama, ar paaugliai diskutuoja apie sveiką mitybą su šeimos nariais. Iš gautų rezultatų paaiškèjo, kad su šeimos nariais sveikos mitybos klausimais dažniau pasitaria sveikų mokyklų tinkle nedalyvaujančių mokyklų mokiniai (palyginus su SMM ugdytiniais) $\left(\chi^{2}=10,6 ; 11 \mathrm{~s}=2 ; \mathrm{p}=0,005\right)$. Maitintis reikia reguliariai - ne mažiau kaip tris kartus per dieną tuo pačiu laiku, reikia rinktis maistingą, ịvairų, dažniau augalinès nei gyvulinès kilmès maistą. Būtent tokie yra pagrindiniai sveikos mitybos principai, kuriuos būtina diegti jauname amžiuje, kadangi šiuo metu formuojasi pagrindiniai žmogaus igūdžiai ir ịpročiai. Racionali mityba yra ypatingai reikšminga augančiam ir besivystančiam organizmui. Taigi apklausos metu buvo aktualu išsiaiškinti, ar mokiniai laikosi sveikos mitybos principų ir palyginti duomenis pagal tai, kokioje mokykloje jie mokosi. Sveikos mitybos principų laikosi statistiškai reikšmingai daugiau mokinių, kurie lanko iprastines mokyklas, o ne sveikatą stiprinančias mokyklas $\left(\chi^{2}=7,3 ; 11 \mathrm{~s}=2 ; \mathrm{p}=0,026\right) .7,0$ proc. sveikatą stiprinančių mokyklų ugdytinių visada laikosi sveikos mitybos principu, 75,2 proc. - laikosi kartais, 17,8 - niekada jų nesilaiko. 13,1 proc. paauglių iš mokyklų, kurios nedalyvauja sveikatą stipinančių mokyklų tinkle, visada laikosi sveikos mitybos principu, 75,1 pro.- laikosi kartais, 11,8 proc. nesilaiko niekada. Apklausos metu buvo nustatyti pagrindiniai šaltiniai, iš kurių mokiniai norètų sužinoti apie sveiką mitybą (4 lentelè). Sveikos gyvensenos pamokose apie sveiką mitybą norètų sužinoti apie pusę (53,3 proc.) mokinių iš sveikatą stiprinančių mokyklų ir 27,8 proc. paaugliu, kurie mokosi mokyklose, neịsitraukusiose į sveikatą stiprinančių mokyklų tinklą. Daugiau nei pusè (58,3 proc.) SSM mokinių abejoja savo žiniomis apie sveiką mitybą, o 35,1 proc.- teigia, kad turi šių žinių pakankamai. Iš gautų duomenų matyti, kad SMM mokiniai turi reikšmingai daugiau žiniu apie sveiką mitybą, nei SMM veikloje nedalyvaujančių mokyklų ugdytiniai $\left(\chi^{2}=13,1 ; 11 s=2 ; p=0,001\right)$ (5 lentelè). Savo mitybos ịpročius statistiškai reikšmingai labiau norètų keisti sveikatą stipinančių mokyklų ugdytiniai, nei SMM veikloje nedalyvaujančių mokyklų mokiniai $\left(\chi^{2}=7,1 ; 11 \mathrm{~s}=2 ; \mathrm{p}=0,029\right)$.

Paauglių mitybos ịpročių situacija Lietuvoje rodo, jog yra aktualu gilintis i paauglių mitybos ịpročius ir siekti, kad paaugliai pradètų laikytis mitybos režimo ir atsisakytų vartoti nesveikus maisto produktus. Pastaruoju metu aktyvẻjantis Lietuvos mokyklų ịsijungimas ị sveikatą stipinančių mokyklų tinklą yra vienas iš būdų, naudojamų stiprinti vaikų ir paauglių sveikatą bei ugdyti sveikos mitybos ịpročius. Tyrimas atskleide, kad pagal daugumą tirtų rodiklių iš sveikatą stiprinančių mokyklų paaugliai pasižymi tinkamesnèmis mitybos nuostatomis, nei nedalyvaujančių sveikatą stiprinančių mokyklų tinkle. Visgi pagal kai kuriuos kriterijus sveikatą stiprinančių mokyklų ugdytinių mitybos ịpročiai atsilieka nuo ịprastinėse mokyklose besimokančiu respondentų mitybos igūdžių. Tai rodo, kad sveikos mitybos aktualijos išlieka tarp svarbių vaikų ir paauglių sveikatos problemų, o sveikos mitybos valdymas mokyklose išlieka prioritetine visuomenès sveikatos priežiūros sritimi.

Sveikatos stiprinimas mokykloje padeda užtikrinti ir sveikos mitybos organizavimą mokykloje [8]. Sveikos mitybos valdymui reikia kurti kompleksines programas, visapusiškas strategijas, pagrịstas glaudžiu bendradarbiavimu ir sąveika tarp ịvairiais lygmenimis vykdomos sveikatinimo veiklos. Perspektyvios, moksliškai pagrịstos, ilgalaikès, sveikatą stiprinančios strategijos, sveikos mitybos igūdžiu formavimas mokyklose, koordinuojamas sveikos mitybos valdymas padètų spręsti vaikų ir paauglių sveikatinimo problemas mūsų šalyje.

\section{Išvados}

1. Kasdien mokykloje pietauja du kartus daugiau mokinių iš sveikatą stiprinančių mokyklų (SSM), nei mokinių, lankančiu mokyklas, nedalyvaujančias sveikatą stiprinančių mokyklų tinkle. 
2.Sveikatą stiprinančių mokyklų mokiniai valgo reikšmingai daugiau kartų per dieną (keturis ir daugiau kartų per dieną), negu mokiniai mokyklose, neįsitraukusiose i sveikatą stiprinančių mokyklų tinklą (tris kartus per dieną).

3. Sveikatą stiprinančių mokyklų tinkle nedalyvaujančiose mokyklose daugiau mokinių nurodé, kad jų mokyklose prekiaujama nesveiku maistu, nei sveikatą stiprinančiose mokyklose.

4. Sveikatą stiprinančių mokyklų mokiniai rečiau valgo greito maisto produktų, geria kokakolos bei kitų saldžių gazuotų gèrimų ir dažniau valgo sriubos, tačiau valgo mažiau juodos duonos ir šviežiu vaisių, nei sveikatą stiprinančių mokyklų veikloje nedalyvaujančių mokyklų ugdytiniai.

5. Maistą mokykloje pagal naudą sveikatai renkasi tik apie 10 proc. paaugliu ir sveikatą stiprinančiose mokyklose, ir ịprastinèse mokyklose.

6. Iprastines mokyklas lankantys mokiniai dažniau kalbasi su šeimos nariais apie sveiką mitybą, dažniau laikosi sveikos mitybos principų, turi daugiau žinių apie sveiką mitybą, nei sveikatą, tačiau savo mitybos ịpročius labiau linkę keisti sveikatą stiprinančių mokyklų ugdytiniai.

7. Sveikos gyvensenos pamokose apie sveiką mitybą norètų sužinoti apie pusè sveikatą stiprinančių mokyklų mokinių ir trečdalis mokinių, lankančių ịprastines mokyklas.

\section{Literatūra}

1. Grabauskas V, Petkevičienė J, Kriaučionienė V, Klumbienė J. Health inequalities in Lithuania: education and nutrition habits. Medicina (Kaunas) 2004; 40(9):875-883.

2. Vereecken C, Ojala K, Jordan M. Eating Habits. In: Currie C. et all. Young people's health in context. Copenhagen: World Health Organization, 2004.

3. Keski-Rahkonen A, Hoek HW, Susser ES, Linna MS, Sihvola E, Raevuori A. et all. Epidemiology and course of anorexia nervosa in the community. American Journal of Psychiatry 2007; 164(8):1259-1265.

4. Zaborskis A., Lagūnaitè R. Vaisiai ir daržovès mokinio valgiaraštyje: mityba ir socialiniai netolygumai $2002-2010$ metais. Visuomenès sveikata, 2011; 2(53): 65 - 75.

5. Stukas R., Savickaja K., Bartkevičiūtè R., Dobrovolskij V. Vilniaus pradinių mokyklų mokinių mitybos ypatumai. Sveikatos mokslai, 2011; 7(21):85-90.
6. Šurkienė G., Stukas R. Ivvairaus amžiaus vaikų mityba ir jos vertinimas. Vilnius. Vilniaus universiteto leidykla, 2003.

7. Jociūtė A. Europos sveikatą stiprinančių mokyklų tinklas. Vilnius. Valstybinis aplinkos sveikatos centras, 2002.

8. Jociūtè A., Krupskienė A., Sabaliauskienė D., Paulauskienė N. Sveikatos stiprinimas mokyklose. Vilnius. Valstybinis aplinkos sveikatos centras, 2008.

\section{TEENAGERS‘ NUTRITION IN HEALTH-PROMOTING SCHOOLS}

S. Griškonis, A. Dabašinskienė, B. Strukčinskienė

Key words: nutrition, teenagers, health-promoting school, schoolchildren, healthy lifestyle.

Summary

The survey on teenagers' nutrition was conducted in four Klaipeda County schools. In the survey participated 487 schoolchildren, aged 15 - 19 years (from 9 - 12 forms): 223 (45.8\%) boys and 264 (54.2\%) girls. In the study, $242(49.7 \%)$ respondents were from health-promoting schools and $245(50.3 \%)$ - from the regular schools. Random cluster sample and Chi-square test were used, and the significance level $p<0.05$ was considered as statistically significant. The study revealed that two times more schoolchildren from health-promoting schools eat daily lunch at school when compare with teenagers from regular schools. The schoolchildren from health - promoting schools eat four or more times per day, while schoolchildren from regular schools - three times per day. From the regular schools more schoolchildren stated that in their school they could buy unhealthy food. Schoolchildren from healthpromoting schools more rare eat fast food, drink carbonated drinks, and more often eat soup, but eat less dark bread and less fresh fruits than that of teenagers from regular schools. While selecting meals at school, only $10 \%$ of schoolchildren from both types of schools the priority give to the value of food for health. Teenagers from the regular schools more often discuss healthy nutrition issues with their family, more often use a healthy diet, and have more knowledge on healthy nutrition than teenagers from health-promoting schools; however schoolchildren from health-promoting schools are more inclined to change their eating habits. The half of schoolchildren from health-promoting schools and one third - from the regular schools prefer to learn on healthy nutrition during the lessons on healthy lifestyle.

Correspondence to: birutedoctor@hotmail.com

Gauta 2014-07-23 